Конструкція і теорія сільськогосподарських машин Construction and theory of agricultural machines

УДК 631.333

https://doi.org/10.37700/enm.2020.2(16).60 - 68

\title{
Експериментальні дослідження нерівномірності розподілу мінеральних добрив за напрямком їх розсіювання
}

\author{
В.М. Булгаков ${ }^{1}$, О.В. Адамчук ${ }^{2}$, В.П. Кувачов ${ }^{3}$ \\ ${ }^{1}$ Національний університет біоресурсів і природокористування України; \\ (м.Київ, Україна)email: vbulgakov@meta.ua; ORCID: 0000-0003-3445-3721 \\ 2 Національний науковий центр «lнститут механізації та електрифрікації \\ сільського господарства» Національної академії аграрних наук (Глеваха, Україна) \\ 3 Таврійський державний агротехнологічний університет імені Дмитра Моторного; \\ (м.Мелітополь, Україна) ORCID: 0000-0002-5762-256X
}

Мета. Підвищення ефективності технологічного процесу внесення мінеральних добрив відцентровими дисковими тукорозсівними робочими органами, осі яких установлені похило.

Методи. В процесі експериментальних досліджень використовували основні положення ГОСТ 20315-75 «Сельскохозяйственная техника. Методика определения условий испытаний», ГОСТ 28714-2007 «Машины для внесения твердых минеральных удобрений. Методы испытаний».

Розрахунки виконували із застосуванням програмного середовища Microsoft Office Excel 2007.

Результати. На нерівномірність розсівання мінеральних добрив за напрямом їх сходження 3 ТОН найбільш вагоме значення оказує частота обертання диска. Отримані результати дозволяють обрати раціональні параметри і режими роботи ТОН у варіанті його розміщення на машинах для внесення добрив.

Висновки.

1. Збільшення частоти обертання диска ТОН від 600 до 800 об/хв має місце зростання ефективної дальності розсівання мінеральних добрив за напрямком їх розсівання на рівні 10,5 м. 3більшення кута нахилу диска до горизонтальної площини до 200 призводить до збільшення ефективної дальності розсівання добрив на рівні 48 деко (24 м) включно, а також збільшення відстані від ТОН до дека з максимальною часткою маси висіяного добрива (5,1 \%) до 24 деко (12 м).

2. При постійній частоті обертання диска ТОН на всіх кінематичних режимах його роботи збільшення кута установки його диска до горизонтальної площини призводить до зростання показників, які характеризують розподіл мінеральних добрив по дека за напрямком їх розсівання.

3. Регулювати ширину розсівання мінеральних добрив можна частотою обертів диска ТОН при його установці під кутом до горизонтальної площини, аналогічно як це має місце в сучасних машинах для внесення добрив за горизонтального положення диска відцентрового робочого органу.

4. Збільшення кута нахилу диска до горизонтальної площини призводить до зростання показників, які характеризують дальність розсівання мінеральних добрив і робочу ширину захвату машини для їх внесення. При цьому інтенсивність збільшення зазначених показників є найбільш високою при збільшенні кута нахилу диска до горизонтальної площини від $0^{\circ}$ до $10^{\circ}$ і зменшується по мірі його наступного збільшення до $30^{\circ}$.

5. Найбільш вагомий вплив на коефіцієнт варіації розподілу мінеральних добрив за напрямком їх розсівання має частота обертання диска ТОН.

Ключові слова: мінеральні добрива, розсівання, розподіл, нерівномірність, дисковий робочий орган, частота обертання, кут установки диску.

Постановка проблеми. Загальновідомо, що дози машинного внесення мінеральних добрив і нерівномірність їх розподілу на поверхні ґрунту впливають не тільки на урожайність сільськогосподарських культур, але і на якість вирощеного урожаю. Зокрема, зменшення нерівномірності внесення добрив з 30\% до 15\% призводить до змен- шення втрат урожаю 3 8,6-22,4\% до 0,6-1,1\% [1, 2]. 3 цього випливає, що чим з меншою нерівномірністю машини вносять добрива, тим буде більший ефрект від їх застосування. Однак реалії створення нових машин показують, що зменшення нерівномірності внесення добрив призводить до необхідності створення більш складних і вищих за ціною 
технічних засобів, що обумовлено народногосподарською задачею, суть якої полягає в низької продуктивності роботи машин для внесення мінеральних добрив та хімічних меліорантів та їх низької техніко-економічної ефективності.

Це приводить до вирішення науково-технічної задачі з підвищення продуктивності роботи машин для внесення мінеральних добрив та хімічних меліорантів і зменшення питомих витрат на виконання цього технологічного процесу.

Аналіз останніх досліджень і публікацій. Питання підвищення ефективності технологічного процесу внесення мінеральних добрив в ґрунт були і залишаються у вчених всього світу актуальними. Науковцями встановлено [3-5], що ефективність використання мінеральних добрив залежить не тільки від самих добрив, але і від способів їх внесення. Головним з факторів, які обмежують ефективність внесення добрив, $є$ нерівномірність їх розподілу по площі поля. Останнє суттєво впливає на дозрівання рослин, строкатість врожаю і його зниження [6].

Водночас на ефективність використання мінеральних добрив впливає і глибина їх закладення. За результатами проведених досліджень $[7,8]$ випливає, що закладення добрив на глибину 18-24 см призводить до їх недоступності рослинам у початковий період росту, а при загортанні різними боронами і культиваторами живильні речовини розміщуються у верхньому пересихаючому шарі ґрунту (0-6 см) вони також не можуть в повній мірі використовуватись рослинами. Багатьма науковцями доведено $[7,8]$, що внесені добрива повинні являтись безпосереднім джерелом живлення для рослин і їх необхідно розташовувати в ґрунті таким чином, щоб вони були легкодоступними активній частині кореневої системи. Розміщення добрив поблизу коренів створює зону підвищеної концентрації живильних речовин. Це полегшує їх поглинання і підвищує ефективність використання. Добрива необхідно розташовувати як у верхніх, так і в більш глибоких шарах ґрунту, з концентрацією пропорційно розвитку кореневої системи рослин [9-11].

Теоретичними і експериментальними дослідженнями відцентрових дискових тукорозсівних робочих органів (ТО) займалась велика кількість як вітчизняних, так і закордонних вчених. Вони вивчали вплив конструкційних форм виконання дисків, лопаток та інших елементів конструкції ТО, параметрів та режимів їх роботи, фрізико-механічних властивостей мінеральних добрив та хімічних меліорантів, умов роботи машин на їх робочу ширину захвату, зокрема, дальність розсівання, нерівномірність внесення добрив тощо. Але розглядувані ними схеми та параметри відцентрових дискових робочих органів не враховували фактор нахилу їх осей у поздовжньо-вертикальній площині. Водно- час в результаті попередніх досліджень процесу внесення мінеральних добрив новим відцентровим робочим органом, осі якого установлені похило (ТОН), нами доведено вагомість цього фактора. Через це проведення ґрунтовних експериментальних досліджень вдосконаленого робочого органу для розсіювання мінеральних добрив $є$ актуальним завданням.

Мета досліджень. Підвищення ефективності технологічного процесу внесення мінеральних добрив відцентровими дисковими тукорозсівними робочими органами, осі яких установлені похило.

Методи досліджень. Експериментальна установка для досліджень з розсівання мінеральних добрив ТОН була спроектована і виготовлена у пересувному варіанті виконання (рис. 1).

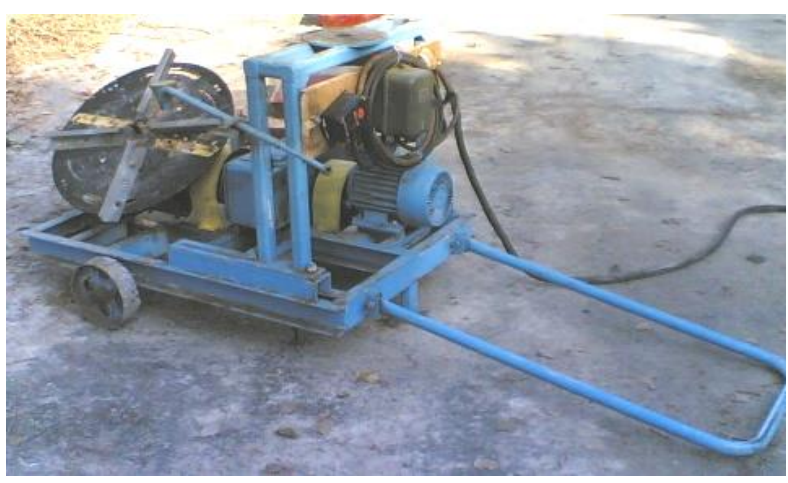

Рис. 1. Загальний вигляд експериментальної установка для дослідження процесу внесення мінеральних добрив відцентровими дисковим тукорозсівним робочим органом, ось якого установленіа похило

На рухомій рамі установки (див. рис. 1) передбачена її можливістю повороту у горизонтальній площині завдяки поворотній рамі, на якій установлювали бункер. В днищі бункера є висівний отвір, обладнаний заслінкою, яка слугувала для регульованої зміни площі живого перерізу зазначеного отвору. Конструкція привода ТОН передбачала можливість як зміни частоти обертання його диска, так і можливість регулювання кута нахилу диска до горизонтальної площини.

Процес роботи експериментальної установки був таким. Крутний момент з електродвигуна через з'єднувальну муфту передавався на вхідний вал ланцюгового варіатора, який змінював частоту обертання, його вихідний вал приводив в обертальний рух через обгінну муфту вхідний вал конічний редуктор. В результаті цього приводився в обертальний рух вихідний вал конічного редуктора, на якому був установлений ТОН. Добрива із бункера через живий переріз висівного отвору під дією гравітаційної сили в дозованій кількості висівались і поступали на ТОН, де захвачувались лопатками, які були в обертальному русі. Попавши 
на лопатки, добрива розганялись, рухаючись під дією відцентрової сили вздовж лопаток у напрямку від центра диска до їх периферійних кінців. Досягши периферійних кінців лопаток добрива сходили з них і завдяки отриманому запасу кінетичної енергії здійснювали рух у повітряному середовищі за певною траєкторією у напрямку від ТОН до поверхні майданчика.

Для дослідження впливу частоти обертання диска та кута його нахилу до горизонтальної площини на нерівномірність розподілу добрив за напрямом їх розсівання (тобто за напрямом, який перпендикулярний до осі експериментальної установки) було заплановано двохфакторний експеримент з декількома рівнями варіювання факторів. При цьому нерівномірність розподілу добрив оцінювалася коефіцієнтом варіації їх розподілу по стандартних дека.

Математичний опис процесів здійснювався шляхом отримання рівнянь регресії. Для цього були обрані такі фактори:

- $n$ - частота обертання диска ТОН в натуральному значенні;

- $\alpha$ - кут нахилу диска до горизонтальної площини в натуральному значенні;

- $X_{1}$ - частота обертання диска в кодованому значенні;

- $X_{2}$ - кут нахилу диска до горизонтальної площини в кодованому значенні.

Експериментальне дослідження нерівномірності розподілу мінеральних добрив ТОН по деках за напрямком їх розсівання здійснювалося із математичним плануванням багатофакторного експерименту у відповідності із план-матрицями (табл. 1-3) [12].

Таблиця 1. План-матриця повнофакторного експерименту дослідження нерівномірності розподілу суперфосфрату гранульованого

ТОН за напрямком його розсівання

\begin{tabular}{|c|c|c|}
\hline \multirow{2}{*}{$\begin{array}{c}\text { № } \\
\Pi / n\end{array}$} & \multicolumn{2}{|c|}{$\begin{array}{c}\text { Значення факторів: } \\
\text { в натуральних (кодованих) } \\
\text { значеннях }\end{array}$} \\
\cline { 2 - 3 } & $n$, об/хв., $\left(X_{1}\right)$ & $\alpha$, град., $\left(X_{2}\right)$ \\
\hline 1 & $600(-1)$ & $30(-2)$ \\
\hline 2 & $600(-1)$ & $20(-1)$ \\
\hline 3 & $600(-1)$ & $10(0)$ \\
\hline 4 & $600(-1)$ & $0(+1)$ \\
\hline 5 & $800(0)$ & $30(-2)$ \\
\hline 6 & $800(0)$ & $20(-1)$ \\
\hline 7 & $800(0)$ & $10(0)$ \\
\hline 8 & $800(0)$ & $0(+1)$ \\
\hline 9 & $1000(+1)$ & $30(-2)$ \\
\hline 10 & $1000(+1)$ & $20(-1)$ \\
\hline 11 & $1000(+1)$ & $10(0)$ \\
\hline 12 & $1000(+1)$ & $0(+1)$ \\
\hline
\end{tabular}

Після проведення експериментальних досліджень на ПК проводили обробку їх результатів для отримання регресивної моделі, яка характеризує вплив факторів і їх взаємодії на нерівномірність розподілу добрив ТОН по дека за напрямком їх розсівання за стандартними методиками статистичної обробки $[12,13]$.

Таблиця 2. План-матриця повнофакторного експерименту дослідження нерівномірності розподілу ТОН нітроамофоски, селітри аміачної за напрямком ї розсівання

\begin{tabular}{|c|c|c|}
\hline \multirow{2}{*}{ № п/п } & \multicolumn{2}{|c|}{ Значення фракторів: } \\
& в натуральних (кодованих) значеннях \\
\cline { 2 - 3 } & $n$, об/хв., $\left(X_{1}\right)$ & $\alpha$, град., $\left(X_{2}\right)$ \\
\hline 1 & $600(-1)$ & $30(-2)$ \\
\hline 2 & $600(-1)$ & $20(-1)$ \\
\hline 3 & $600(-1)$ & $0(+1)$ \\
\hline 4 & $800(0)$ & $30(-2)$ \\
\hline 5 & $800(0)$ & $20(-1)$ \\
\hline 6 & $800(0)$ & $0(+1)$ \\
\hline
\end{tabular}

На першому етапі обробки даних, після отримання їх перевіряли на відтворюваність. Для оцінки відтворюваності застосовували критерій Кохрена, значення якого визначали за залежністю:

$$
G=\frac{S_{u \max }^{2}}{\sum_{u=1}^{n} S_{u}^{2}} \leq G_{\text {таб }}
$$

де $G_{\text {таб }}\left(0,05 ; n ; f_{u}\right)$ - табличне значення критерію Кохрена при 5\%-ому рівні значимості, при числі дослідів $n$ і числі степенів свободи $f_{u}=m-1$ із числом повторностей $m$.

Дисперсію визначали згідно такого виразу:

$$
S_{u}^{2}=\frac{1}{m-1} \sum_{i=1}^{m}\left(y_{u i k}-\overline{y_{u}}\right)^{2},
$$

де $y_{\text {uik }}-$ значення вихідного параметру на відповідній повторності.

Після цього похибку досліду розраховували таким чином:

$$
S_{y}^{2}=\frac{1}{n} \sum_{u=1}^{n} S_{u}^{2} .
$$

Якщо в результаті перевірки за допомогою критерію Кохрена доводили, що процес відтворюваний, то наступним кроком в обробці результатів експериментальних даних було визначення коефріцієнтів регресії згідно таких фрормул:

$$
\begin{gathered}
b_{0}=\frac{1}{n} \sum_{i=1}^{n} \overline{y_{u}}, \quad b_{p}=\frac{1}{n} \sum_{i=1}^{n} X_{p} \bar{y}, \\
b_{p r}=\frac{1}{n} \sum_{i=1}^{n} X_{p} X_{r} \bar{y} .
\end{gathered}
$$


Перевірку адекватності рівняння регресії проводили за критерієм Фішера:

$$
F=\frac{S_{a d}^{2}}{S_{y}^{2}}<F_{\text {таб }},
$$

де $S_{a d}^{2}=\frac{1}{f_{a d}} \sum_{u=1}^{n}\left(y-\overline{y_{u}}\right)^{2}$ - дисперсія адекватності; $f_{a d}=n-k-1-$ число ступенів свободи дисперсії адекватності при кількості фракторів рівному $k ; f_{y}=n(m-1)$ - число ступенів свободи дисперсії відтворюваності.

Після цього проводили оцінку значимості коефіцієнтів рівняння регресії з використанням критерію Стьюдента. Умова значимості коефіцієнта рівняння регресії мала такий вигляд:

$$
\left|b_{i}\right| \geq t_{\text {таб }} \cdot \frac{S_{y}}{\sqrt{n}},
$$

де $t_{\text {таб }}$ - табличне значення критерію Стьюдента при 5\%-ому рівні значимості.

Кореляційний аналіз дослідних даних дозволяв визначити наявність зв'язку між факторами.

Коефіцієнт кореляції між величинами $x$ і $y$ визначали так:

$$
r_{x y}=\frac{K_{x y}}{S_{x} S_{y}},
$$

де $S_{x}, S_{y}$ - середньоквадратичне відхилення відповідних величин; $K_{x y}-$ кореляційний момент.

Якщо коефіцієнт кореляції рівний нулю, то величини некорельовані, а якщо коефіцієнт кореляції більший 0,7 - кореляційний зв'язок сильний, 0,3...0,7 - середній, менше 0,3 - слабкий.

Середньоквадратична похибка коефіцієнта кореляції визначалася за допомогою такого виразу:

$$
S_{r}=\sqrt{\frac{1-r_{x y}^{2}}{n-2} .}
$$

Кореляційний зв'язок між параметрами істотний за умови, що розрахункове значення критерію Стьюдента є більшим за його табличне значення:

$$
t_{r}=\frac{r_{x y}}{S_{y}} \geq t_{\text {таб }} .
$$

В процесі експериментальних досліджень використовували основні положення ГОСТ 20315-75 «Сельскохозяйственная техника. Методика определения условий испытаний», ГОСТ 28714-2007. «Машины для внесения твердых минеральных удобрений. Методы испытаний».

Лабораторні дослідження проводили за таких значень основних режимів роботи експериментальної установки і конструктивних параметрів ТОН:

- частота обертання диска ТОН: 600 об/хв., 800 та 1000 об/хв.;
- кут нахилу диска до горизонтальної площини: $0^{\circ}, 10^{\circ}, 20^{\circ}, 30^{\circ}$;

- діаметр диска - 650 мм;

- радіус подачі добрив - 150 мм.

Нерівномірність розподілу мінерального добрива оцінювали за величиною коефіцієнта варіації:

$$
v=\frac{100 \sigma}{\bar{m}}
$$

де $\sigma$ - середньоквадратичне відхилення; $m_{i}-$ маса гранул добрива в $i$-му деко; $n$ - кількість деко.

Результати досліджень. За результатами дослідження впливу частоти обертання диска TOH на характер розподілу селітри аміачної за напрямом її розсівання побудовано графічні залежності, які наведено на рис. 2.

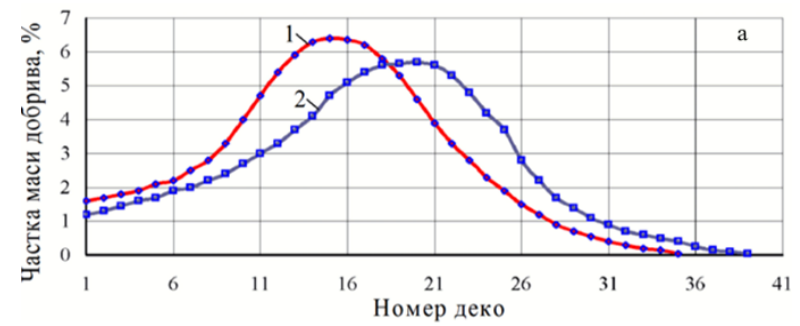

a

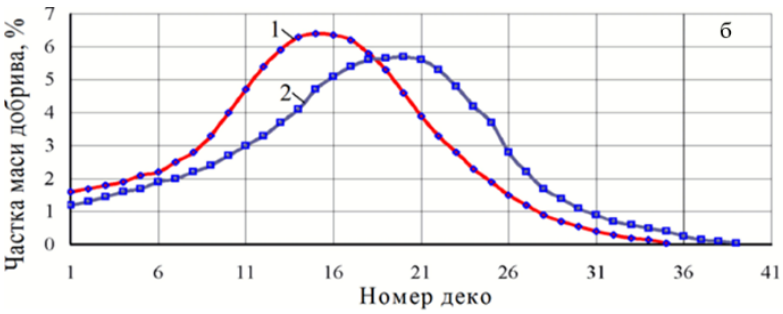

б

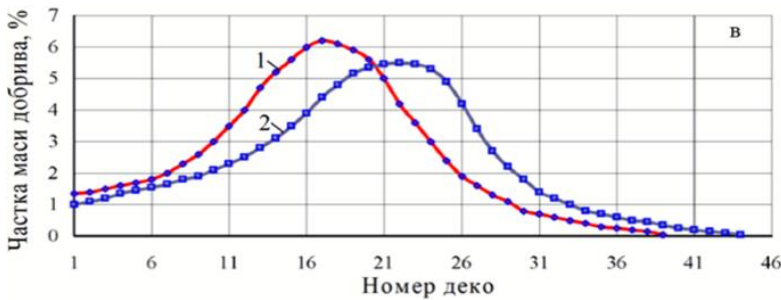

B

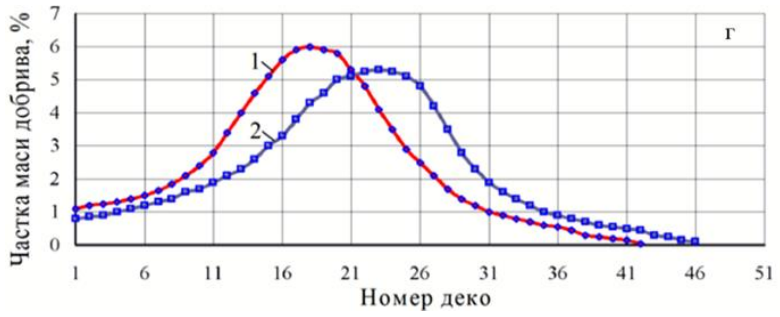

Рис. 2. Залежність розподілу селітри аміачної ТОН за напрямком її розсівання по деках від частоти обертання диска: а, б, в, г - кут нахилу диска до горизонтальної площини відповідно $0^{\circ}, 10^{\circ}, 20^{\circ}, 30^{\circ} ; 1,2$ - частота обертання диска відповідно 600 та 800 об/хв. 
Експериментальними дослідженнями встановлено, що за горизонтального положення диска та частоти його обертання 600 об/хв. ефективна дальність розсівання селітри аміачної за напрямком її розподілу сягає 30 деко включно (15 м), максимальна частка добрива (7,2\%) висівається в 12 деко (6 м). Збільшення частоти обертання диска ТОН до 800 об/хв. призводить до збільшення довжини ділянки, на якій ефективного розсівається селітра аміачна, до 35 деко включно (17,5 м). При цьому максимальна частка маси добрива (6,3 \%) висівається в 15 деко (7,5 м).

Отже, за горизонтального положення диска ТОН збільшення частоти його обертання від 600 до 800 об/хв. призводить до зростання ефективної дальності розсівання селітри аміачної на 16,7 \%, відстань від ТОН до дека, в яке поступила максимальна частка маси висіяного добрива, зростає на $25 \%$, а максимальна частка маси добрива, висіяного в дека, зменшилась в 1,14 разів.

Аналогічні закономірності впливу частоти обертання диска ТОН на розподіл селітри аміачної за напрямком її розсівання мають місце і за умови збільшення кута нахилу диска до горизонтальної площини до $30^{\circ}$ (див. риС. 2). Як видно з графрічних залежностей, криві 2, які відповідають характеру розподілу селітри аміачної за частоти обертання диска 800 об/хв., суттєво зміщені вправо у порівнянні з кривими 1, які відповідають характеру розподілу селітри аміачної за частоти обертання диска 600 об/хв. Тобто є доцільним проаналізувати вплив зміни кута установки диска $\mathrm{TOH}$ до горизонтальної площини на показники розподілу селітри аміачної по деках за напрямком іії розсівання.

За частоти обертання диска ТОН 600 об/хв. та кута установки його диска до горизонтальної площини $10^{\circ}$ (рис. 3) селітра аміачна ефективно розсівається на ділянці до 35 деко (18,5 м) включно, а максимальна частка добрива (6,4\%) висівається в 15 деко (7,5 м). У варіанті установки диска під кутом до горизонтальної площини 20 ефрективне розсівання селітри аміачної відбувається на ділянці до 39 деко (19,5 м) включно, а максимальна частка маси добрива (6,2\%) висівається в 17 деко (8,5 м). Збільшення кута установки диска до горизонтальної площини до 30 призводить до збільшення ефективної дальності розсівання селітри аміачної до 42 деко (21 м) включно, максимальна частка маси добрива (6 \%) висівається у 18 деко (9 м).

Таким чином було встановлено, що за частоти обертання диска ТОН 600 об/хв. зміна кута установки диска ТОН від $0^{\circ}$ до:

- 10 призводить до збільшення ефективної дальності розсівання селітри аміачної на 16,7 \%, відстані від ТОН до дека з максимальною часткою маси висіяного добрива - на $25 \%$ та зменшення зазначеної частки маси селітри аміачної у 1,13 разів;

- 20 призводить до збільшення ефективної дальності розсівання селітри аміачної на $30 \%$, відстані від ТОН до дека з максимальною часткою маси висіяного добрива - на 41,7 \% та зменшення зазначеної частки маси селітри аміачної у 1,16 разів;

- 30॰ призводить до збільшення ефективної дальності розсівання селітри аміачної на $40 \%$, відстані від ТОН до дека з максимальною часткою маси висіяного добрива - на $50 \%$ та зменшення зазначеної частки маси селітри аміачної у 1,2 рази.

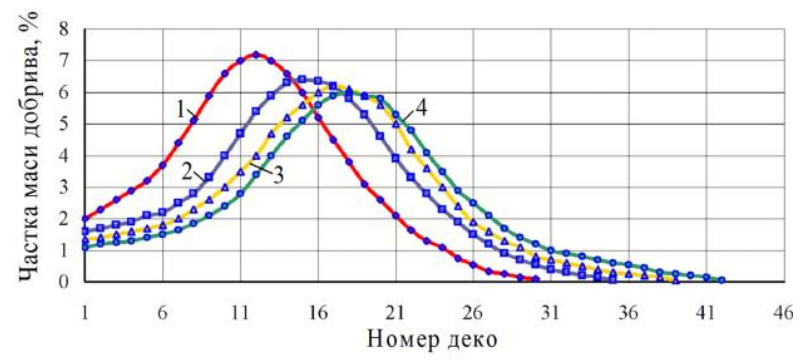

Рис. 3. Залежність розподілу селітри аміачної TOH за напрямком її розсівання по деках за частоти обертання диска 600 об/хв. від кута його нахилу до горизонтальної площини:

1, 2, 3 - кут нахилу диска до горизонтальної площини відповідно $0^{\circ}, 10^{\circ}, 20^{\circ}, 30^{\circ}$

За частоти обертання диска ТОН 800 об/хв. та кута установки його диска до горизонтальної площини $10^{\circ}$ (рис. 4) селітра аміачна ефективно розсівається на ділянці до 39 деко (19,5 м) включно, а максимальна частка маси добрива $(5,7 \%)$ висівається в 20 деко (10 м).

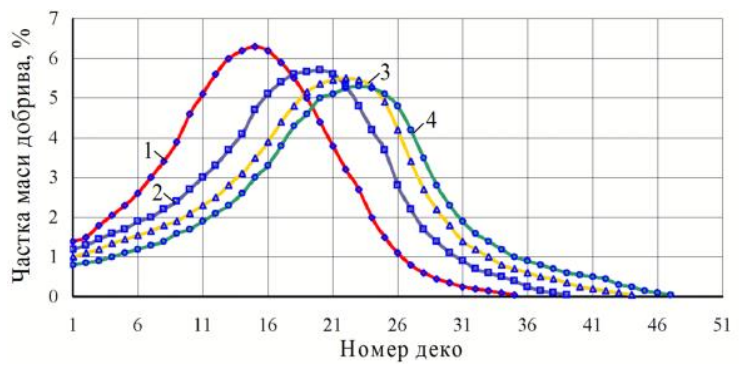

РиС. 4. Залежність розподілу селітри аміачної TOH за напрямом її розсівання по деках за частоти обертання диска 800 об/хв. та кута його нахилу до горизонтальної площини:

1, 2, 3 - кут нахилу диска до горизонтальної площини відповідно $0^{\circ}, 1^{\circ}, 20^{\circ}, 30^{\circ}$

У варіанті установки диска під кутом до горизонтальної площини 20० ефективне розсівання селітри аміачної відбувається на ділянці до 44 деко (22 м) включно, а максимальна частка маси 
добрива (5,5\%) висівається в 22 деко (11 м). Збільшення кута установки диска до горизонтальної площини до $30^{\circ}$ призводить до збільшення ефрективної дальності розсівання селітри аміачної до 47 деко $(23,5$ м) включно, максимальна частка маси добрива $(5,3 \%)$ висівається в 23 деко (11,5 м).

Таким чином було встановлено, що за частоти обертання диска ТОН 800 об/хв. зміна кута установки диска ТОН від $0^{\circ}$ до:

- $10^{\circ}$ призводить до збільшення ефективної дальності розсівання селітри аміачної на $11,4 \%$, відстані від ТОН до дека 3 максимальною часткою маси висіяного добрива - на 33,3 \% та зменшення зазначеної частки маси селітри аміачної у 1,1 разів;

- $20^{\circ}$ призводить до збільшення ефективної дальності розсівання селітри аміачної на $25,7 \%$, відстані від ТОН до дека 3 максимальною часткою маси висіяного добрива - на 46,7 \% та зменшення зазначеної частки маси селітри аміачної у 1,15 разів;

- 30 призводить до збільшення ефективної дальності розсівання селітри аміачної на $34,3 \%$, відстані від ТОН до дека з максимальною часткою маси висіяного добрива - на 53,3 \% та зменшення зазначеної частки маси селітри аміачної у 1,19 разів.

Результати дослідження розподілу селітри аміачної ТОН за напрямком її розсівання по дека показують, що зі збільшенням частоти обертання диска від 600 до 800 об/хв. в межах всіх досліджуваних значень кута установки диска ТОН до горизонтальної площини, має місце зростання як ефрективної дальності розсівання селітри аміачної, так і відстані від ТОН до дека з максимальною часткою маси висіяного добрива.

Наприклад, збільшення ефективної дальності розсівання селітри аміачної становить за кута: $0^{\circ}-16,7 \%, \quad 10^{\circ}-11,4 \%, \quad 20^{\circ}-12,8 \%$, $30^{\circ}-11,9 \%$, а збільшення відстані від ТОН до дека з максимальною часткою маси висіяного добрива буде становити за кута: $0^{\circ}-25,0 \%$, $10^{\circ}-33,3 \%, 20^{\circ}-29,4 \%, 30^{\circ}-27,8 \%$.

При постійній частоті обертання диска ТОН на всіх кінематичних режимах його роботи збільшення кута установки диска ТОН до горизонтальної площини призводило до зростання показників, які характеризують розподіл селітри аміачної по деках за напрямком ії розсівання. Зокрема, за частоти обертання диска ТОН 800 об/хв., зростання ефективної дальності розсівання селітри аміачної становить при збільшенні кута нахилу диска ТОН від горизонтального його положення до: $10^{\circ}-11,4 \%, 20^{\circ}-25,7 \%, 30^{\circ}-34,3 \%$, а збільшення відстані від ТОН до дека з максимальною часткою маси висіяного добрива буде становити: $10^{\circ}-33,3 \%, 20^{\circ}-46,7 \%, 30^{\circ}-53,3 \%$.
Викладене підтверджує, що оборотами диска ТОН можна регулювати ширину розсівання селітри аміачної при його установці під кутом до горизонтальної площини, аналогічно як це має місце в сучасних машинах для внесення добрив за горизонтального положення диска ТОН.

Збільшення кута нахилу диска до горизонтальної площини призводить до зростання показників, які характеризують дальність розсівання селітри аміачної і робочу ширину захвату машини для внесення мінеральних добрив. При цьому інтенсивність збільшення зазначених показників $є$ найбільш високою при збільшенні кута нахилу диска до горизонтальної площини від $0^{\circ}$ до $10^{\circ}$ і зменшується по мірі його наступного збільшення до $30^{\circ}$.

Отже, ТОН з похилою віссю обертання забезпечує зростання показників, що характеризують розподіл селітри аміачної за напрямком її розсівання, на більшу відстань ніж забезпечує ТО з вертикальною віссю обертання. Таким чином підтверджується гіпотеза щодо можливості збільшення робочої ширини захвату машин для внесення мінеральних добрив на операції внесення селітри аміачної шляхом обладнання таких машин ТOH.

Рівняння регресії впливу частоти обертання диска і кута його нахилу до горизонтальної площини на нерівномірність розподілу селітри аміачної за напрямком її розсівання мають такий вигляд:

$$
\begin{gathered}
y=-101,4-0,0574 n+ \\
+4,6034 \alpha-0,0256 \alpha^{2}
\end{gathered}
$$

Аналізом залежності (11) встановлено, що на нерівномірність розсівання гранул селітри аміачної за напрямом ії сходження з ТОН найбільший вплив має значення частоти обертання диска.

Аналогічно були отримані рівняння регресії, які описуватимуть характер розподілу суперфосфату гранульованого за напрямом його розсівання ТОН:

$$
\begin{gathered}
y=18,2533+0,0992 n-0,3063 \alpha- \\
-0,000092 n^{2}+0,0037 \alpha^{2}+0,00011 n \alpha .
\end{gathered}
$$

Із аналізу отриманої регресії (12) встановлено, що найбільш вагомий вплив на коефіцієнт варіації розподілу суперфосфату гранульованого за напрямком його розсівання має також частота обертання диска ТОН.

За результатами реалізації двофракторного експерименту отримано залежність коефріцієнта варіації розподілу нітроамофооски за напрямком її розсівання від кута нахилу диска ТОН до горизонтальної площини та частоти його обертання:

$$
\begin{gathered}
y=80,46-0,0312 n-0,3825 \alpha- \\
-0,000037 n^{2}+0,0018 \alpha^{2}+0,00046 n \alpha .
\end{gathered}
$$


Аналогічно до результатів досліджень виразів (11) та (12) встановлено, що найбільш вагоме значення на нерівномірність розсівання нітроамофоски за напрямом сходження добрив з ТОН має частота обертання диска.

Отримані результати дозволяють обрати раціональні параметри і режими роботи ТОН у варіанті його розміщення на машинах для внесення добрив. Але слід прийняти до уваги. що для отримання показників нерівномірності внесення добрив на робочій ширині захвату машини, обладнаної двома ТОН, коли з кожного ТОН добриво сходить не окремою полосою, а віялом з центральним кутом близьким до 90, необхідно проводити польові досліди, в процесі яких трактор з машиною для внесення добрив буде проїжджати залікову ділянку, на якій за стандартною методикою будуть установлені дека для збору висіяного добрива.

\section{Висновки.}

1. Збільшення частоти обертання диска ТОН від 600 до 800 об/хв має місце зростання ефективної дальності розсівання мінеральних добрив за напрямком їх розсівання на рівні 10,5 м. Збільшення кута нахилу диска до горизонтальної площини до $20^{\circ}$ призводить до збільшення ефективної дальності розсівання добрив на рівні 48 деко (24 м) включно, а також збільшення відстані від $\mathrm{TOH}$ до дека з максимальною часткою маси висіяного добрива (5,1 \%) до 24 деко (12 м).

2. При постійній частоті обертання диска ТОН на всіх кінематичних режимах його роботи збільшення кута установки його диска до горизонтальної площини призводить до зростання показників, які характеризують розподіл мінеральних добрив по дека за напрямком їх розсівання.

3. Регулювати ширину розсівання мінеральних добрив можна частотою обертів диска ТОН при його установці під кутом до горизонтальної площини, аналогічно як це має місце в сучасних машинах для внесення добрив за горизонтального положення диска відцентрового робочого органу.

4. Збільшення кута нахилу диска до горизонтальної площини призводить до зростання показників, які характеризують дальність розсівання мінеральних добрив і робочу ширину захвату машини для їх внесення. При цьому інтенсивність збільшення зазначених показників є найбільш високою при збільшенні кута нахилу диска до горизонтальної площини від $0^{\circ}$ до $10^{\circ}$ і зменшується по мірі його наступного збільшення до $30^{\circ}$.

5. Найбільш вагомий вплив на коефіцієнт варіації розподілу мінеральних добрив за напрямком їх розсівання має частота обертання диска ТОН.

\section{Література:}

1. Адамчук В.В. Автомобільна машина для внесення мінеральних добрив. Аграрна наука виробництву. 1998. № 2. С. 28.

2. Адамчук В.В., Мойсеєнко В.К. Дослідження залежності дальності польоту мінеральних добрив від кута нахилу лопаток розсівального органу до горизонтальної площини. Міжвідомчий тематичний науковий збірник. Механізація та електрифікація сільського господарства. 2004. Вип. 88. С. 23-36.

3. Калетнік Г.М., Адамчук В.В., Петриченко Є.А. та ін. Теорія плоскопаралельного руху удобрювально-посівного машинно-тракторного агрегату. Техніка, енергетика, транспорт АПК. 2017. Вип. 2 (97). С. 6-18.

4. Адамчук В.В., Петриченко Є.А., Булгаков В.М. та ін. Теоретичне обґрунтування стійкого руху нового удобрювально-посівного агрегату. Конструювання, виробництво та експлуатація сільськогосподарських машин. 2017. Вип. 47, ч.1. C. 11-31.

5. Булгаков В.М., Адамчук В.В., Петриченко Є.А. та ін. Теоретичне дослідження нового удобрювально-посівного агрегату. Механізація та електрифікація сільського господарства. 2017. Вип. № 6 (105). С. 11-25.

6. Адамчук В.В., Мойсеєнко В.К. Експериментальне дослідження відбиття мінеральних добрив лопатками розсіювальних органів. Мeханізація та електрифікація сільського господарства. 2003. Вип. 87. С. 32-41.

7. Дейкун В.А., Сало В.М., Васильковський О.М. Аналіз способів внесення мінеральних добрив. Наукові записки. 2004. Вип. 5. С. 12-15.

8. Каминьски Е., Каминьски Я., Адамчук В.В., Барановский В.Н. Прогресс в технике для применения минеральных удобрений. Механізація та електрифікація сільського господарства. 2002. Вип. 86. С. 99-103.

9. Корчинська О.А. Методичні аспекти оцінки ефективності застосування мінеральних добрив в умовах ринку. Економіка АПК. 2002. № 10. - C. 71-76.

10. Сучасні тенденції розвитку конструкцій сільськогосподарської техніки / В.І. Кравчук та ін. - Київ: Аграрна наука, 2004. 396 с.

11. Ясенецький В., Шейченко В. Розкидачі мінеральних добрив для господарств усіх форм власності. Техніка АПК. 2002. № 12. С. 16-17.

12. Гмурман В.Е. Теория вероятностей и математическая статистика: учебник для СПО. Москва: Издательство Юрайт, 2016. - 479 с.

13. Жильцов О.Б. Теорія ймовірностей та математична статистика у прикладах і задачах: навч. посіб. Київ: Університет ім. Б. Грінченка, 2015. 336 c. 


\section{References:}

1. Adamchuk, V.V. (1998) 'Avtomobilna mashyna dlia vnesennia mineralnykh dobryv', Ahrarna nauka - vyrobnytstvu, (2), p. 28.

2. Adamchuk, V.V. and Moiseienko, V.K. (2004) 'Doslidzhennia zalezhnosti dalnosti polotu mineralnykh dobryv vid kuta nakhylu lopatok rozsivalnoho orhanu do horyzontalnoi ploshchyny', Mizhvidomchyi tematychnyi naukovyi zbirnyk. Mekhanizatsiia ta elektryfikatsiia silskoho hospodarstva, (88), pp. 23-36.

3. Kaletnik, H.M. and Adamchuk, V.V. Petrychenko, Y.A. (2017) 'Teoriia ploskoparalelnoho rukhu udobriuvalno-posivnoho mashynnotraktornoho ahrehatu', Tekhnika, enerhetyka, transport APK, (2(97)), pp. 6-18.

4. Adamchuk, V.V., Petrychenko, Y.A. and Bulhakov, V.M. (2017) 'Teoretychne obgruntuvannia stiikoho rukhu novoho udobriuvalno-posivnoho ahrehatu', Konstruiuvannia, vyrobnytstvo ta ekspluatatsiia silskohospodarskykh mashyn, 1(47), pp. 11-31.

5. Bulhakov, V.M., Adamchuk, V.V. and Petrychenko, Y.A. (2017) 'Teoretychne doslidzhennia novoho udobriuvalno-posivnoho ahrehatu', Mekhanizatsiia ta elektryfikatsiia silskoho hospodarstva, (6(105)), pp. 11-25.

6. Adamchuk, V.V. and Moiseienko, V.K. (2003)
'Eksperymentalne doslidzhennia vidbyttia mineralnykh dobryv lopatkamy rozsiiuvalnykh orhaniv', Mekhanizatsiia ta elektryfikatsiia silskoho hospodarstva, (87), pp. 32-41.

7. Deikun, V.A., Salo, V.M. and Vasylkovskyi, O.M. (2004) 'Analiz sposobiv vnesennia mineralnykh dobryv', Naukovi zapysky, (5), pp. 12-15.

8. Kaminski, E. et al. (2002) 'Progress v tehnike dlya primeneniya mineralnyih udobreniy', Mekhanizatsiia ta elektryfikatsiia silskoho hospodarstva, (86), pp. 99-103.

9. Korchynska, O.A. (2002) 'Metodychni aspekty otsinky efektyvnosti zastosuvannia mineralnykh dobryv v umovakh rynku', Ekonomika APK, (10), pp. 71-76.

10. Adamchuk, V.V., Baranov, H.L. and Baranovskyi, O. S. (2004) Suchasni tendentsii rozvytku konstruktsii silskohospodarskoi tekhniky. Edited by V. I. Kravchuk. Kyiv: Ahrarna nauka.

11. Yasenetskyi, V. and Sheichenko, V. (2002) 'Rozkydachi mineralnykh dobryv dlia hospodarstv usikh form vlasnosti', Tekhnika APK, (12), pp. 16-17.

12. Gmurman, V.E. (2016) Teoriya veroyatnostey i matematicheskaya statistika: uchebnik dlya SPO. Moskva: Izdatelstvo Yurayt.

13. Zhyltsov, O.B. (2015) Teoriia ymovirnostei ta matematychna statystyka u prykladakh $i$ zadachakh: navch. posib. Kyiv: Universytet im. B. Hrinchenka, $336 \mathrm{p}$.

\title{
Аннотация
}

\section{Экспериментальные исследования неравномерности распределения мине- ральных удобрений по направлению их рассеяния}

\author{
В.М. Булгаков, О.В. Адамчук, В.П. Кувачов
}

Цель. Повышение эффективности технологического процесса внесения минеральных удобрений центробежными дисковыми тукорозсивными рабочими органами, оси которых установлены наклонно.

Методы. В процессе экспериментальных исследований использовались основные положения ГОСТ 20315-75 «Сельскохозяйственная техника. Методика определения условий испытаний», ГОСТ 28714-2007 «Машины для внесения твердых минеральных удобрений. Методы испытаний».

Расчеты выполнялись с применением программной среды Microsoft Office Excel 2007.

Результаты. Неравномерность рассева минеральных удобрений по направлению их схода с ТОН наиболее весомое значение оказывает частота вращения диска. Полученные результаты позволяют выбрать оптимальные параметры и режимы работы ТОН в варианте его размещения на машинах для внесения удобрений.

Выводы.

1. Увеличение частоты вращения диска ТОН от 600 до 800 об/мин приводит к росту эффрективной дальности рассева минеральных удобрений по направлению их рассева на уровне 10,5 м. Увеличение угла наклона диска к горизонтальной плоскости до $20^{\circ}$ приводит к увеличению эфффективной дальности рассева удобрений на уровне 48 деко $(24$ м) включительно, а также увеличения расстояния от ТОН до деко с максимальной долей массы высеянных удобрения $(5,1 \%)$ до 24 деко (12 м).

2. При постоянной частоте вращения диска ТОН на всех кинематических режимах его работы увеличение угла установки его диска в горизонтальной плоскости приводит к росту показателей, характеризующих распределение минеральных удобрений по деко в направлении их рассева.

3. Регулировать ширину рассева минеральных удобрений можно частотой оборотов диска ТОН при его установке под углом к горизонтальной плоскости, подобно тому, как это имеет место в современных машинах для внесения удобрений при горизонтальном положении диска центробежного рабочего органа.

Інженерія природокористування, 2020, №2(16), С. 60 - 68

Engineering of nature management, 2020, \#2(16), p. 60 - 68 
4. Увеличение угла наклона диска к горизонтальной плоскости приводит к росту показателей, характеризующих дальность рассева минеральных удобрений и рабочую ширину захвата машины для их внесения. При этом интенсивность увеличения указанных показателей является наиболее высокой при увеличении угла наклона диска к горизонтальной плоскости от 0 до $10^{\circ}$ и уменьшается по мере его последующего увеличения до $30^{\circ}$.

5. Наиболее существенное влияние на коэффициент вариации распределения минеральных удобрений по направлению их рассева оказывает частота вращения диска ТОН.

Ключевые слова: минеральные удобрения, рассев, распределение, неравномерность, дисковый рабочий орган, частота вращения, угол установки диска.

Abstract

\title{
Experimental studies of the regular distribution of mineral fertilizers in the direction of their scattering
}

\author{
V.M. Bulgakov, O.V. Adamchuk, V.P. Kuvachov
}

Purpose. Increasing the efficiency of the technological process of introducing mineral fertilizers by centrifugal disc tukorozvny working bodies, the axes of which are installed obliquely.

Methods. In the process of experimental research, the basic provisions of GOST 20315-75 "Agricultural machinery. Method for determining test conditions", GOST 28714-2007“" Machines for applying solid mineral fertilizers. Test methods".

The calculations were performed using the Microsoft Office Excel 2007 software environment.

Results. The irregularity of the sowing of mineral fertilizers in the direction of their descent from the OET has the most significant effect on the rotational speed of the disk. The results obtained make it possible to select the optimal parameters and modes of operation of the OET in the variant of its placement on machines for applying fertilizers.

Conclusions.

1. An increase in the rotational speed of the TON disk from 600 to $800 \mathrm{rpm}$ leads to an increase in the effective sieving range of mineral fertilizers in the direction of their sieving at the level of $10.5 \mathrm{~m}$. An increase in the disc inclination angle to the horizontal plane up to $20^{\circ}$ leads to an increase in the effective sieving range of fertilizers by level of 48 deco $(24 \mathrm{~m})$ inclusive, as well as increasing the distance from OET to deco with the maximum proportion of the sown fertilizer mass $(5.1 \%)$ to 24 deco (12 m).

2. With a constant rotational speed of the TON disk in all kinematic modes of its operation, an increase in the angle of installation of its disk in the horizontal plane leads to an increase in indicators characterizing the distribution of mineral fertilizers in deco in the direction of their sieving.

3. The sowing width of mineral fertilizers can be adjusted by the frequency of revolutions of the TON disc when it is installed at an angle to the horizontal plane, similar to what is the case in modern machines for applying fertilizers when the disc of the centrifugal working body is horizontal.

4. An increase in the angle of inclination of the disc to the horizontal plane leads to an increase in the indicators characterizing the sieving range of mineral fertilizers and the working width of the machine for their introduction. In this case, the intensity of the increase in these indicators is the highest with an increase in the angle of inclination of the disc to the horizontal plane from 0 to $10^{\circ}$ and decreases as it further increases to $30^{\circ}$.

5. The most significant influence on the coefficient of variation of the distribution of mineral fertilizers in the direction of their sieving is exerted by the frequency of rotation of the OET disk.

Keywords: mineral fertilizers, sieving, distribution, unevenness, disk working body, rotation frequency, disc angle.

\section{Бібліографічне посилання/ Bibliography citation: Harvard}

Bulgakov, V. M., Adamchuk, O. V. and Kuvachov, V. P. (2020) 'Experimental studies of the regular distribution of mineral fertilizers in the direction of their scattering', Engineering of nature management, (2(16)), pp. 60 - 68.

Подано до редакції / Received: 04.08.2020 